UDC 616.98: 579.835.12

DOI: 10.21668/health.risk/2018.3.13.eng

Read

online

\title{
INFLUENCE EXERTED BY HELICOBACTER PYLORI ON CONCENTRATIONS OF ANTI-INFLAMMATORY T-CELL CYTOKINES AND SUNPOPULATIONS THAT PRODUCE THEM
}

\author{
M.I. Tsyganova ${ }^{1}$, M.V. Talaeva ${ }^{1}$, V.Yu. Talaev ${ }^{1}$, N.V. Neumoina ${ }^{1}$, K.M. Perfilova ${ }^{1}$, \\ E.V. Mokhonova ${ }^{1}$, V.A. Lapin ${ }^{1,2}$, D.A. Melent'ev ${ }^{1,2}$
}

${ }^{1}$ Nizhniy Novgorod Research Institute of Epidemiology and Microbiology named after Academician I.N. Blokhina, 71 Malaya Yamskaya Str., Nizhniy Novgorod, 603950, Russian Federation

${ }^{2}$ Nizhniy Novgorod National Research State University named after N.I. Lobachevskiy, 23 Gagarina avenue,

Nizhniy Novgorod, 603022, Russian Federation

Helicobacter pylori is a widely spread pathogenic microorganism. It penetrates the mucous tunic of the stomach and the duodenum and causes diseases in the gastrointestinal tract, including oncologic ones. This agent is able to be chronically persistent in a body and frequently there are no apparent symptoms of it; therefore, it is difficult to detect this pathogen in due time. Risk analysis related to occurrence and development of various pathologies associated with Helicobacter pylori, revealed that their clinical course was to a great extent determined by an immune response that emerged after infection. There are data that Helicobacter pylori is able to influence protective immune reactions making their balance to move to an increase in immune-suppressive components, for example, increased concentrations of T-regulatory cells and cytokines produced by them. However, some data can be found on Helicobacter pylori ability to induce anti-inflammatory responses which include those associated with T-helpers of the 1st and 17th types. Our research goal was to reveal peculiarities of effects produced by this pathogen on $\gamma$-interferon as one of basic products by 1st type T-helpers and on contents of the 17th type T-helpers determined as cells belonging to $\mathrm{CD}^{+} \mathrm{CD}^{+} 61^{+}$and $\mathrm{CD} 4^{+} \mathrm{IL} 17^{+}$phenotypes under direct contacts between bacteria and lymphocytes. Our research objects were clinical isolates of Helicobacter pylori and blood samples taken from people without helicobacter infection in their case history. We extracted lymphocytes with immunomagnetic separation out of mononuclear blood cells obtained via functioning in density gradient. Their concentrations were assessed with cytofluorometry; cytokines products, with enzyme-linked immunosorbent assay. We showed that $\mathrm{CD}^{+} \mathrm{CD} 161^{+}$and $\mathrm{CD}^{+} \mathrm{IL1} 7^{+}$cells content didn't change when they were cultivated together for 18 hours under influence exerted by Helicobacter pylori, while products of $\gamma$-interferon increased considerably. It can probably be related to activation of the 1st type T-helpers under effects produced by direct contact with bacteria. However, we didn't detect any activation of the 17th type T-helpers. Therefore, we can assume that effects produced by Helicobacter pylori on T-helpers under direct contact cause a response in a form of the 1st type T-helpers activation.

Key words: Helicobacter pylori, lymphocytes, T-helpers, differentiation, co-stimulation, антитела, flow cytofluorometry, cell cultures.

(C) Tsyganova M.I., Talaeva M.V., Talaev V.Yu., Neumoina N.V., Perfilova K.M., Mokhonova E.V., Lapin V.A., Melent'ev D.A., 2018

Mariya I. Tsyganova - Candidate of Biological Sciences, Head of Immune Chemistry Laboratory (e-mail: lab.imchem@nniiem.ru; tel.: +7 (831) 469-79-56).

Mariya V. Talaeva - Candidate of Biological Sciences, Senior researcher at Cellular Immunology Laboratory (e-mail: micro@sinn.ru; tel.: +7 (831) 469-79-48).

Vladimir Yu. Talaev - Doctor of Medical Sciences, Head of Cellular Immunology Laboratory (e-mail: micro@ sinn.ru; tel.: +7 (831) 469-79-48).

Natal'ya V. Neumoina - Candidate of Medical Sciences, Chief Physician at Infectious Diseases Clinic (e-mail: micro@sinn.ru; tel.: +7 (831) 433-01-68).

Kseniya M. Perfilova - Candidate of Medical Sciences, Deputy to Chief Physician responsible for expert research at Infectious Diseases Clinic (e-mail: micro@sinn.ru; tel.: +7 (831) 433-74-66).

Ekaterina V. Mokhonova - Junior researcher at Immune Chemistry Laboratory (e-mail: lab.imchem@nniiem.ru; tel.: +7 (831) 469-79-56).

Vladislav A. Lapin - Junior researcher at Immune Chemistry Laboratory, student (e-mail: lab.imchem@ nniiem.ru; tel.: +7 (831) 469-79-56).

Dmitriy A. Melent'ev - Junior researcher at Immune Chemistry Laboratory, student (e-mail: lab.imchem@nniiem.ru; tel.: +7 (831) 469-79-56) 
Contemporary healthcare faces variable vital tasks, and one of them is to analyze risk factors that cause occurrence and development of diseases in the gastrointestinal tract. All the age groups are susceptible to risks of damage to the digestive organs, including employable population, elderly people, children, and teenagers. High costs related to necessary treatment and rehabilitation of patients which can be rather expensive make prevention and anti- recurrent treatment of such pathologies not only medical, but also a social problem.

Helicobacter pylori (H. pylori) is a widely spread pathogenic microorganism associated with gastrointestinal tract diseases. $H$. pylori is well proven to selectively colonize the mucous tunic of the stomach and duodenum and is considered to be an etiological agent that causes acute and chronic gastritis, ulcer, and other diseases in the gastrointestinal tract $[1,2]$. H. pylori has a distinctive peculiarity which is its ability to persist in a body for a long time, and this persistence quite often has no symptoms thus making the detection and eradication of the pathogen rather complicated. Such an effect is produced via impacts exerted by the pathogen on the immune system of its host that result in activation of its immune-suppressing component [3, 4]. This hypothesis is confirmed by data found in literature that in some cases helicobacter infection makes for less apparent clinical course of autoimmune and allergic diseases [5, 6].

Besides, $H$. pylori was proven to promote an authentic increase in contents of FoxP3positive T-regulatory cells (T-reg) and cytokines produced by them; such results were obtained during laboratory tests on model animals $[7,8]$. There is also a discussion in the literature on $H$. pylori ability to influence immune cells directly in the stomach thus stimulating changes both in their activity and in levels of cytokines produced by them [9-11]. H. pylori ability to stimulate Treg generation under a direct contact between bacteria and human responder lymphocytes in vitro was described in our previous paper [12]. But at the same time, when attempts were made to reproduce the effect both in vivo and in vitro, there was an increase in anti-inflammatory cytokines such as gamma-interferon INF- $\gamma$ (INF- $\gamma$ ) and interleukin-17A (IL-17A), and also, apart from T-reg, there was an induction of the 1st and 17th type T-helpers (Th1 и Th17) [13-15].

INF- $\gamma$ and IL-17A play quite a variable role in development of gastroenterological pathologies. They participate in eliminating infectious agents by neutrophils and macrophages. It is a violent response by the immune system, that is considered to be the most probable cause for development of acute pathologies in the gastrointestinal tract in case of infections with $H$. pylori $[16,17]$. However, apart from it, at present IL-17 and Th17 that produce them are viewed as the most probable basic mediators of $\mathrm{H}$. pyloriassociated autoimmune gastritis [18]. Data on participation of Th1 and cytokines produced by them in autoimmune gastritis development are rarely found but the role they play in development of other autoimmune pathologies has been studied and outlined quite profoundly [19, 20]. So, induction of INF- $\gamma$ and IL-17A and subpopulations that produce them detected under interaction with $H$. pylori can lead to occurrence of both inflammatory pathologies in the stomach and duodenum and a wide range of extragastroduodenal diseases that is confirmed by data taken from literature [21].

Given all the above said, there is a vital scientific and practical task to assess antiinflammatory effects by $H$. pylori and mechanisms that determine proneness of the agent to both regulatory and anti-inflammatory action. Besides, a preliminarily revealed ability of $H$. pylori directly, without any participating antigen-presenting cells (APC), influence at least some human T-cells subpopulations is also of great interest.

Our research goal was to assess $H$. pylori ability to stimulate occurrence of INF- $\gamma$, IL17A and Th17 under direct contact between bacteria and T-cells, without APC participation.

Data and methods. Our research objects were samples of whole peripheral blood taken from people without $H$. pylori-infection in their case history, its absence confirmed by data obtained via objective research techniques, $(n=8)$, and $H$. pylori isolates taken during diagnostic EGD from people suffering from chronic gastritis $(n=6)$. Blood was only once taken in volume equal to 8-9 $\mathrm{ml}$ into vacuum tubes with sodium heparin (Vacuette, Germany). Samples were treated not later than 2 hours after they had been 
taken. Mononuclear cells of peripheral blood (MCPB) were extracted out of blood samples via centrifuging ( for 45 minutes at 1,500 turns per minute) at "Diakoll-1077" density gradient ("DiaM" Russia). After it, we extracted only $\mathrm{CD} 4^{+}$ cells out of obtained MCPB via immunemagnetic separation with Human naïve CD4+ Tcell enrichment Kit (Stemcell technologies, the USA). H. pylori was extracted out of biopsy materials taken during diagnostic EGD out of the antral section and body of the stomach; biopsy materials were taken from people with positive CLO-test. The materials were ground mechanically and then sowed on Columbian agar (Becton Dickinson, the USA) with added 10-\% defibrinated donor blood as well as with antibiotics for suppressing growth of extraneous microflora and fungi $(10 \mu \mathrm{g} / \mathrm{l}$ of Vancomycin, $5 \mathrm{mg} / \mathrm{l}$ of Trimethoprim, and $2 \mathrm{mg} / \mathrm{l}$ of Nystatin. all produced by Teva, Israel). Cultivating was performed for 7 days under microaerophilic conditions, the temperature being $37^{\circ} \mathrm{C}$. H. pylori was identified on the basis of cultural and morphological features.

To assess influence exerted by $H$. pylori on lymphocytes differentiation, we performed joint cultivation of lymphocytes with various concentrations of bacteria (we applied the following ratios of lymphocytes to $H$. pylori one by one: $1: 10,1: 20,1: 50)$ for 18 hours under the following conditions $5 \% \mathrm{CO} 2,37{ }^{\circ} \mathrm{C}$, RPMI-1640 medium (Gibco, the USA) with added $10 \%$-fetal bovine serum and $0.3 \mathrm{~g} / \mathrm{l}$ of L-glutamine ("Paneko", Russia). A part of lymphocytes was cultivated with bacteria when additional stimulators were present; these stimulators were monoclonal antibodies to CD3 molecule $(1 \mu \mathrm{g} / \mathrm{ml}$, eBioscience, the USA) that imitated influence on T-cell receptor, or a mixture of antibodies to CD3 and CD28 $(1 \mu \mathrm{g} / \mathrm{ml}$, eBioscience, the USA, and $3 \mu \mathrm{g} / \mathrm{ml}$, Beckman Coulter, France), that imitated influence exerted by APC on T-cells. We had the following cultures in our experiment: lymphocytes with added $H$. pylori, but without any stimulating antibodies; lymphocytes with added antibodies to CD3 and without bacteria; lymphocytes with added antibodies to CD3 and with $H$. pylori; lymphocytes with added antibodies to CD3 and CD28, and without $H$. pylo$r i$; and lymphocytes with added antibodies to CD3 and CD28 and with H. pylori. The last cul- ture was included into the experiment in order to assess influence exerted by direct presence of the agent on the nature of stimulation. Experiments for all the ratios of lymphocytes and bacteria were performed separately. Lymphocytes without $H$. pylori and stimulating antibodies were negative controls for all the cultures.

After 18 hours 18 we applied cytofluorometry to estimate Th17 as cells of $\mathrm{CD} 4^{+} \mathrm{CD} 161^{+}$и $\mathrm{CD} 4^{+} \mathrm{IL}-17 \mathrm{~A}^{+}$phenotype in all the cultures. To paint the above mentioned markers, we applied antibodies to CD4 tagged with FITC; antibodies to CD161 tagged with PE; antibodies to IL-17A tagged with PE; all produced by eBioscience, the USA. We performed permeabilization of membranes necessary to tag IL-17A with Fix/Perm Concentrate reagents kit and Perm Buffer reagents kit (eBioscience, the USA) according to manufacturer's instructions. Analysis was conducted with FacsCalibur cytofluorimeter (Beckton Dickinson, the USA). Th1 activity was determined by measuring INF- $\gamma$ concentrations in supernatants of the cultures with ELISA technique (Vector-Best, Russia). we applied Newman-Keuls test to statistically process the obtained data.

Results and discussion. An increase in INF- $\gamma$ level is a significant part in immune response realization. This cytokine is a macrophages activator and it is involved into a direct response to infection attacks; besides, it enhances effects produced by $\alpha$ and $\beta$ interferon, promotes an immune response as per Th1 type, and is able to stimulate activities of antigenrepresenting cells [22].

As we can see from Figure 1, when H. pylo$r i$ was added to a suspension of extracted lymphocytes, both without additional stimulators and together with antibodies to $\mathrm{CD} 3$ or $\mathrm{CD} 3 / \mathrm{CD} 28$, it led to statistically authentic increase in INF- $\gamma$ production.

This production in the control culture was equal to only $10 \pm 4.08 \mathrm{pg} / \mathrm{ml}$; when bacteria were added in a ratio $1: 10$, it went up to $835 \pm 351.4 \mathrm{pg} / \mathrm{ml}$; in a ratio $1: 20,745 \pm 164.1$ $\mathrm{pg} / \mathrm{ml}$; in a ratio $1: 50,135 \pm 121.8 \mathrm{pg} / \mathrm{ml}$. INF- $\gamma$ production in cultures which were additionally stimulated with antibodies had no statistical discrepancies from a variant with only bacterial stimulations; thus, INF- $\gamma$ concentration in a culture consisting of T-lymphocytes with $H$. pylori 


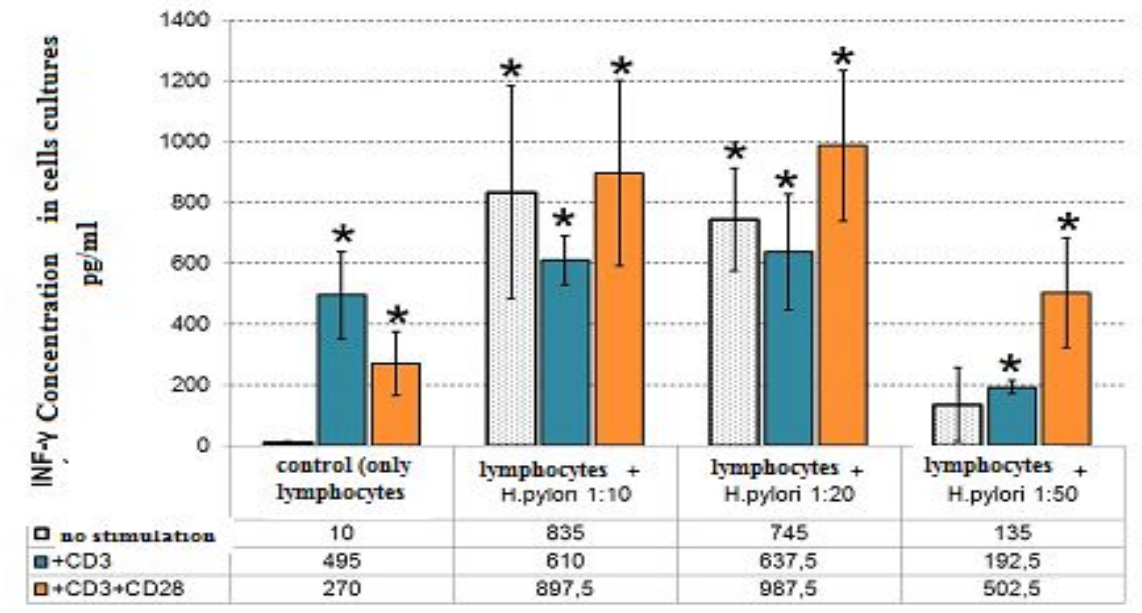

Figure 1. Influence exerted by $H$. pylori on INF- $\gamma$ production. Variants of stimulation are given below the graph. Control is a culture with lymphocytes only, without added bacteria or antibodies, * means there are authentic discrepancies from the control $(\mathrm{p}<0.05)$.

and added antibodies to CD3 amounted to $610 \pm 081.3 \mathrm{pg} / \mathrm{ml}$ at a ratio being $1: 10$; $637.5 \pm 189.7 \mathrm{pg} / \mathrm{ml}$ at a ratio being $1: 20$; and $192.5 \pm 21.3 \mathrm{pg} / \mathrm{ml}$ at a ration being $1: 50$. INF- $\gamma$ concentration in samples with T-lymphocytes with added $H$. pylori and additional stimulation with an admixture of antibodies to CD3 and CD28 amounted to $897.5 \pm 300.1 \mathrm{pg} / \mathrm{ml}$ at a ration being $1: 20 ; 987.5 \pm 249.1 \mathrm{pg} / \mathrm{ml}$ at a ratio being $1: 20 ; 502.5 \pm 180.01 \mathrm{pg} / \mathrm{ml}$ at a ratio being 1:50. All the obtained results coincide with data taken from literature on clinical course of $H$. pylori-associated gastritis accompanied with Th1 accumulation and increased INF- $\gamma$ in the stomach mucous tunic [13].

Figures 2 and 3 show data on influence exerted by $H$. pylori on differentiation of lymphocytes towards Th17 and them acquiring $\mathrm{CD} 4^{+} \mathrm{CD} 161^{+}$phenotype and without any dendritic cells in the cultures.

As we can see, joint cultivation of $H$. pylori and T-cells for 18 hours didn't lead to an increase in $\mathrm{CD} 4{ }^{+} \mathrm{CD} 161^{+}$cells number. Their average number in cultures without bacterial stimulation amounted to $20.065 \pm 0.72 \%$ from all the $\mathrm{CD}^{+}$cells; when $H$. pylori was added to responder lymphocytes in a ratio 10:1, it amounted to $22.15 \pm 1.49 \%$. And concentrations of such cells in cultures with ratios 1:20 and 1:50 also had practically no differences from control concentrations of non-stimulated lymphocytes (the number amounted to $24.2 \pm 3.41 \%$ for a ratio $1: 20$, and to $23.15 \pm 2.73 \%$ for a ratio $1: 50$ ).

To test significance of co-stimulation, we performed additional experiments adding stimulating antibodies to $\mathrm{CD} 3$ and $\mathrm{CD} 3+\mathrm{CD} 28$ molecules; these antibodies sent a signal to $\mathrm{T}$ cells which was similar to that sent by antigenpresenting cells in the process of stimulation. $\mathrm{CD} 4^{+} \mathrm{CD} 161^{+}$cells concentration amounted to $23.745 \pm 7.3 \%$ in a culture of T-lymphocytes without $H$. pylori but with added antibodies to CD3. But at the same time, when both H. pylori and antibodies to $\mathrm{CD} 3$ were added

to a culture, $\mathrm{CD} 4{ }^{+} \mathrm{CD} 161^{+}$cells concentration amounted to $23.83 \pm 3.30 \%$ for a ratio $1: 10$; $25.4 \pm 2.42 \%$ for a ratio $1: 20$; and $25.4 \pm 1.75 \%$ for a ratio 1:50.

CD161 molecule under its co-expression with CD4 molecule is widely used in world scientific practice as a Th17 population marker. However, occurrence of membrane phenotypic markers doesn't guarantee that responder cells are functionally able to produce IL-17A or, in other words, to fulfill basic Th17 function. Also, some authors state, that it is more reliable to assess Th17 concentration as per occurrence of intracellular IL-17A or its products than to apply CD161 in the process. Given all the above stated, we assessed concentrations of intracellular IL-17A in cultures of lymphocytes that responded to $H$. pylori. To do that, we performed permeabilization of responder cells membranes and 


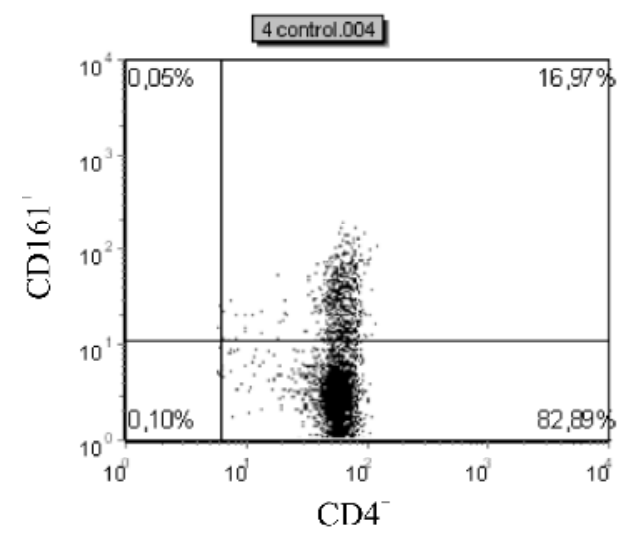

$a$

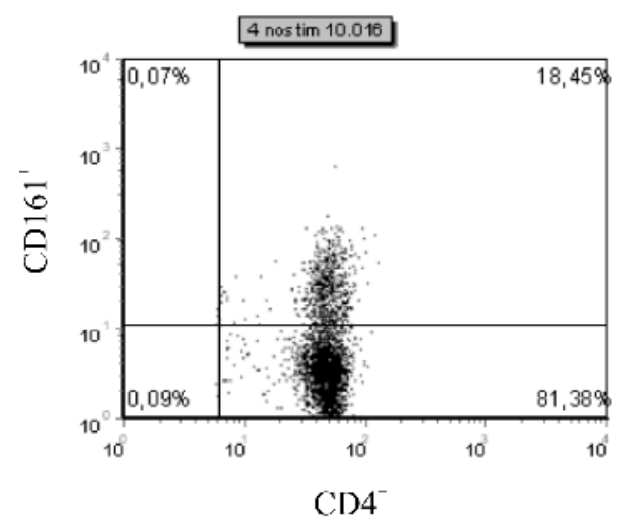

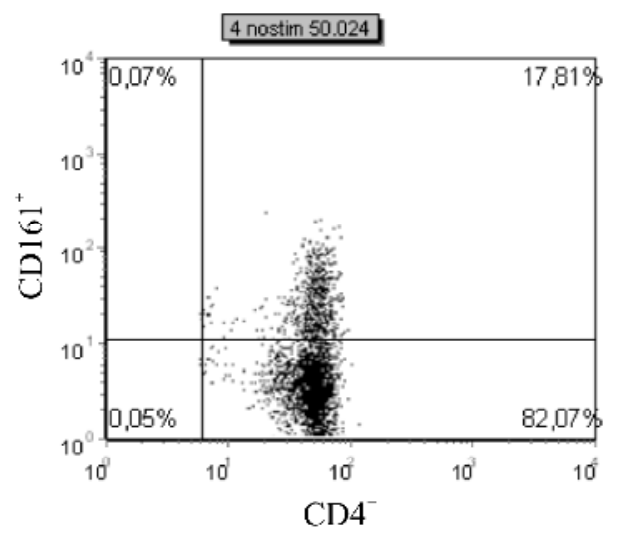

6

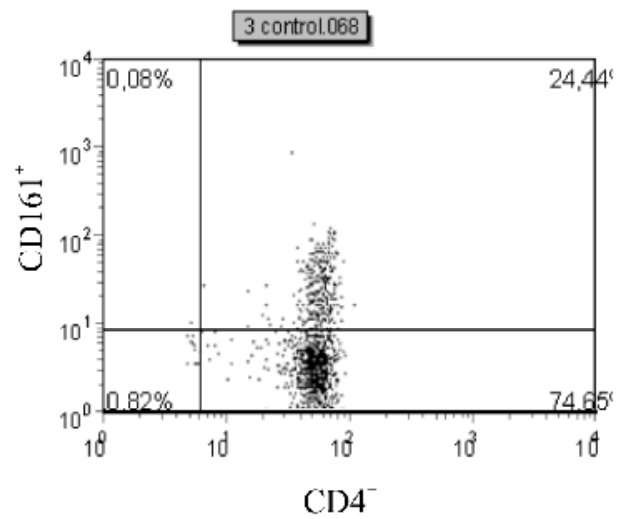

Figure 2. $\mathrm{CD} 4{ }^{+} \mathrm{CD} 161^{+}$cells concentrations in T-lymphocytes cultures under joint cultivation with $\mathrm{H}$. pylori without additional stimulation, in \% of the overall CD4+ cells number (data obtained via a representative experiment): A is a control suspension of lymphocytes without $H$. pylori; $\mathrm{B}$ is joint cultivation with $H$. pylori in a ratio $1: 10, \mathrm{C}$ and $\mathrm{D}$ is joint cultivation with $H$. pylori in ratios 1:20 and 1:50 respectively. A per cent content of cells is given in the angles of the quadrants.

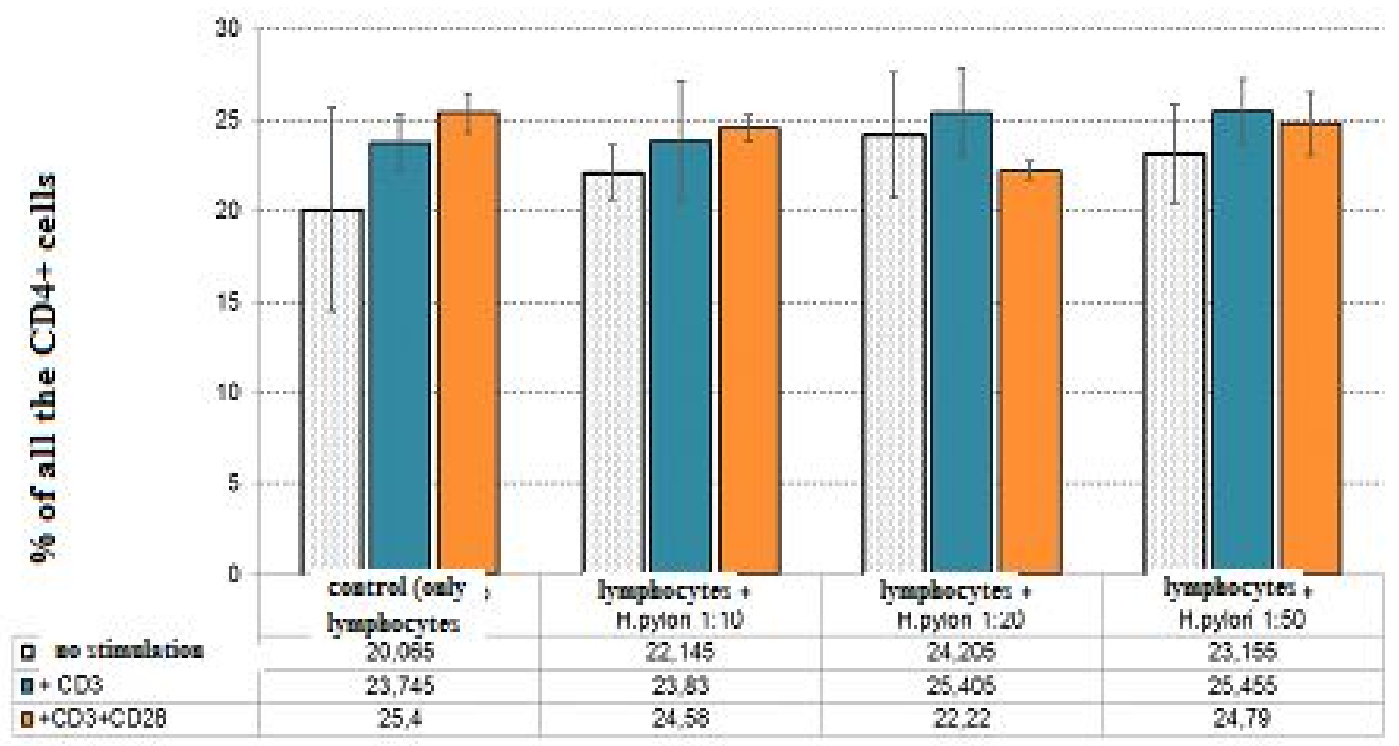

Figure 3. Influence exerted by $\mathrm{H}$. pylori on $\mathrm{CD} 4^{+} \mathrm{CD} 161^{+}$cells concentration. variants of stimulation are given below the graph. Control is a culture with lymphocytes only, without added bacteria or antibodies 
Table

$\mathrm{IL}-17 \mathrm{~A}^{+} \mathrm{CD} 4^{+}$cells concentrations under joint cultivation with $H$. pylori and/or additional stimulation with antibodies to CD3 and CD28

\begin{tabular}{|c|c|c|c|c|c|c|}
\hline \multirow[t]{2}{*}{$\begin{array}{l}{\mathrm{IL}-17 \mathrm{~A}^{+} \text {cells }}_{\text {concentration }} \\
(\% \text { from all } \\
\left.\mathrm{CD} 4^{+} \text {cells }\right)\end{array}$} & $\begin{array}{l}\text { Lymphocytes } \\
\text { without } H . p y \text { - } \\
\text { lori (control) }\end{array}$ & $\begin{array}{l}\text { Lymphocytes } \\
\text { without H.py- } \\
\text { lori, CD3 }\end{array}$ & $\begin{array}{l}\text { Lymphocytes } \\
\text { without } H \text {. py- } \\
\text { lori, CD } 3 \text { and } \\
\text { CD28 }\end{array}$ & $\begin{array}{l}\text { Lymphocytes }+ \\
\text { H. pylori }(1: 10)\end{array}$ & $\begin{array}{c}\text { Lymphocytes }+ \\
\text { H. pylori } \\
(1: 10), \mathrm{CD} 3\end{array}$ & $\begin{array}{l}\text { Lymphocytes + } \\
\text { H. pylori }(1: 10) \text {, } \\
\text { CD3 and CD28 }\end{array}$ \\
\hline & $0,27 \pm 0,08$ & $0,21 \pm 0,02$ & $0,23 \pm 0,033$ & $0,43 \pm 0,07$ & $0,26 \pm 0,03$ & $0,14 \pm 0,04$ \\
\hline
\end{tabular}

painted them with monoclonal antibodies to IL17A. We detected that most cells don't stimulate greater IL-17A expression under cultivation conditions applied in our experiments (Table).

Thus, IL-17 $\mathrm{A}^{+}$cells concentration didn't exceed $0.5 \%$ of all the $\mathrm{CD}^{+}$cells in any of the applied variants of stimulation and ratios of responder cells and bacteria; such concentration doesn't have any discrepancies from standard IL$17^{+}$cells concentration in human blood [23-25].

\section{Conclusions.}

Direct joint cultivation of extracted Tlymphocytes with $H$. pylori promotes a drastic increase in INF- $\gamma$ production, and it, under these experimental conditions, can most probably mean that Th1 activation occurs. However, Th17 concentrations in \% (determined both as $\mathrm{CD} 4^{+} \mathrm{CD} 161^{+}$, and as $\mathrm{CD}^{+} \mathrm{IL} 17 \mathrm{~A}^{+}$) changed only slightly under such conditions. We can assume that a response from T-helpers to a direct contact with $H$. pylori, given its anti-inflammatory effects, develops as per Th1 type, without Th17 being significantly involved in the process. A mechanism that determines $H$. pylori ability to stimulate activity of both Th1 and T-reg (which was shown by us earlier) requires further investigation. Overall, the authors think that mechanisms and acting agents that help a pathogen to exert direct influence on a prevailing type of an immune response are of great fundamental and practical interest; they potentially can be applied in development of medications that guide an immune response to a right direction. They are also important for assessing risks of hyper-stimulated immune response development in patients infected with $H$. pylori.

Funding. The research was not granted any sponsor support.

Conflict of interests. The authors state there is no any conflict of interests.

\section{References}

1. Van der Sloot K.W.J., Amini M., Peters V., Dijkstra G., Alizadeh B.Z. Inflammatory bowel diseases: review of known environmental protective and risk factors involved. Inflamm Bowel Dis., 2017, vol. 9, pp. 1499-1509.

2. Pachathundikandi S.K., Müller A., Backert S. Inflammasome activation by Helicobacter pylori and its Implications for persistence and immunity. Curr. Top. Microbiol. Immunol., 2016, vol. 397, pp. $117-131$.

3. Rosenplänter C., Sommer F., Kleemann P., Belkovets A., Schmidt A., Lohoff M. Helicobacter pylori polyclonally activates murine $\mathrm{CD}^{+} \mathrm{T}$-cells in the absence of antigen-presenting cells. Eur. J. Immunol., 2007, vol. 37, no. 7, pp. 1905-1915.

4. Lerner A., Arleevskaya M., Schmiedl A., Matthias T. Microbes and viruses are bugging the gut in celiac disease. Are they friends or foes? Front Microbiol., 2017, vol. 8, pp. 1392.

5. Chen Y., Blaser M.J. Helicobacter pylori colonization is inversely associated with childhood asthma. J. Infect. Dis., 2008, vol. 198, pp. 553-560.

6. Bartels L.E., Jepsen P., Christensen L.A., Gerdes L.U., Vilstrup H., Dahlerup J.F. Diagnosis of Helicobacter Pylori infection is associated with lower prevalence and subsequent incidence of Crohn's disease. Journal of Crohn's and Colitis, 2016, vol. 10, no. 4, pp. 443-448.

7. Arnold I.C., Dehzad N., Reuter S., Martin H., Becher B., Taube C., Müller A. Helicobacter pylori infection prevents allergic asthma in mouse models through the induction of regulatory T cells. Journal Clin. 
Invest., 2011, vol. 121, no. 8, pp. 3088-3093.

8. Amedei A., Codolo G., Del Prete G., de Bernard M., D'Elios M.M. The effect of Helicobacter pylori on asthma and allergy. Journal Asthma. Allergy, 2010, vol. 3, pp. 139-147.

9. Bamford K.B., Fan X., Crowe Sh.E., Leary J.F., Gourley W.K., Luthra G.K., Brooks E.G., Graham D.Y., Reyes V.E., Ernst P.B. Lymphocytes in the human gastric mucosa during Helicobacter pylori have a T-helper cell 1 phenotype. Gastroenterology,1998, vol. 114, no. 3, pp. 482-492.

10. Tarkkanen J., Kosunen T.U, Saksela E. Contact of lymphocytes with Helicobacter pylori augments natural killer cell activity and Induces Production of Gamma Interferon. Infection and immunity, 1993, vol. 61, no. 7, pp. 3012-3016.

11. Tsai H.-F., Hsu P.-N. Interplay between Helicobacter pylori and immune cells in immune pathogenesis of gastric inflammation and mucosal pathology. Cellular \& Molecular Immunology, 2010, vol. 7, pp. 255-259.

12. Matveichev A.V., Talaeva M.V., Talaev V.Yu., Neumoina N.V., Perfilova K.M., Lapaev D.G., Mokhonova E.V., Tsyganova M.I., Koptelova V.N., Nikitina Z.I., Lapin V.A., Melent'ev D.A. Influence exerted by Helicobacter pylori on regulatory t-cells differentiation. Health Risk Analysis, 2017, no. 1, pp. 21-28. DOI: 10.21668/health.risk/2017.1.03.eng

13. Windle H.J., Ang Y.S., Athie-Morales V., McManus R., Kelleher D. Human peripheral and gastric lymphocyte responses to Helicobacter pylori NapA and AphC differ in infected and uninfected individuals. Gut., 2005, vol. 54, no. 1, pp. 25-32.

14. Käbisch R., MejíasLuque R., Gerhard M., Prinz C. Involvement of Toll-like receptors on Helicobacter pylori-induced immunity. PLoS One, 2014, vol. 9, no. 8, pp. e104804.

15. Shiu J., Blanchard T.G. Dendritic cell function in the host response to Helicobacter pylori infection of the gastric mucosa. Pathog. Dis., 2013, vol. 67, no. 1, pp. 46-53.

16. Tanaka S., Nagashima H., Cruz M., Uchida T., Uotani T., Jiménez Abreu J.A., Mahachai V., Vilaichone R., Ratanachu-ek T., Tshering L., Graham D.Y., Yamaoka Y. Interleukin-17C in human Helicobacter pylori gastritis. Infect Immun., 2017, vol. 85, no. 10, pp. e00389-e00417.

17. Permin H., Andersen L.P. Inflammation, immunity, and vaccines for Helicobacter infection. Helicobacter, 2005, vol. 10, no. 1, pp. 21-25.

18. Huter E.N., Stummvoll G.H., DiPaolo R.J., Glass. D.D., Shevach E.M. Pre-differentiated Th1 and Th17 effector T cells in autoimmune gastritis: ag-specific regulatory $\mathrm{T}$ cells are more potent suppressors than polyclonal regulatory T cells. Int. Immunopharmacol., 2009, vol. 9, no 5, pp. 540-545.

19. Pravada N.S., Budritskii A.M. Kompleksnaya terapiya s primeneniem immunotropnykh preparatov pri tuberkuleze i sistema interferona-gamma [Complex therapy with the use of immune preparations in tuberculosis and interferon-gamma system]. Vestnik Vitebskogo gosu-darstvennogo meditsinskogo universiteta, 2015, vol. 14, no. 4, pp. 5-14 (in Russian).

20. Bazzazi H., Aghaei M., Memarian A., Asgarian-Omran H., Behnampour N., Yasdani Y. Th1Th17 ratio as a new insight in rheumatoid arthritis disease. Iran J. Allergy Asthma Immunol., 2018, vol. 17, no. 1 , pp. $68-77$.

21. Bar-dakhch'yan E.A., Lomov S.Yu., Kharlanova N.G., Kamneva N.V. Rol' Helicobacter Pylori pri razvitii ekstragastroduodenal'nykh zabolevanii [Role of helicobacter pylori in different gastroduodenal diseases]. Eksperimental'naya i klinicheskaya gastroenterologiya, 2005, no. 3, pp. 20-27 (in Russian).

22. Lutskii A.A., Zhirkov A.A., Lobzin D.Yu., Rao M., Alekseeva L.A., Meirer M., Lobzin Yu.V. Interferon- $\gamma$ : biologicheskaya funktsiya i znachenie dlya diagnostiki kletochnogo immunno-go otveta [Interferony: biological function and applicationfor study of cellular immune response]. Zhurnal infektologii, 2015, vol. 7, no. 4, pp. 10-22 (in Russian).

23. Miao J., Zhang K., Qiu F., Li T., Lv M., Guo N., Han Q., Zhu P. Percentages of CD4 ${ }^{+} \mathrm{CD} 161^{+}$and $\mathrm{CD} 4{ }^{-} \mathrm{CD} 8{ }^{-} \mathrm{CD} 161^{+} \mathrm{T}$ cells in the synovial fluid are correlated with disease activity in rheumatoid arthritis. Mediators Inflamm, 2015, vol. 2015, P ID 563713.

24. Church L.D., Filer A.D., E Hidalgo., Howlett K.A., Thomas A.M.C., Rapecki S., ScheelToellner D., Buckley C.D., Raza K. Rheumatoid synovial fluid interleukin-17-producing CD4 T cells have abundant tumor necrosis factor-alpha co-expression, but little interleukin-22 and interleukin-23R expression. Arthritis Res. Ther., 2010, vol. 12, no. 5, pp. R184.

25. Shen H., Goodall J.C, Hill Gaston H.J.S. Frequency and phenotype of peripheral blood Th17 cells in ankylosing spondylitis and rheumatoid arthritis. Arthritis \& Rheumatism., 2009, vol. 60, no. 6, pp. 1647-1656. 
Tsyganova M.I., Talaeva M.V., Talaev V.Yu., Neumoina N.V., Perfilova K.M., Mokhonova E.V., Lapin V.A., Melent'ev D.A. Influence exerted by helicobacter pylori on concentrations of anti-inflammatory m-cell cytokines and sunpopulations that produce them. Health Risk Analysis, 2018, no. 3, pp. 120-127. DOI: 10.21668/health.risk/2018.3.13.eng

Received: 20.06 .2018

Accepted: 20.09.2018

Published: 30.09 .2018 